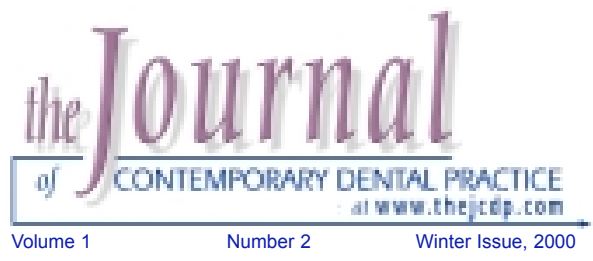

\title{
Odontogenic Keratocyst: The Northwestern USA Experience
}

Dolphine Oda, BDS, MSc

Valiente Rivera, DDS; N. Ghanee, DDS, MSD; E.A. Kenny, MA; K.H. Dawson, BDS

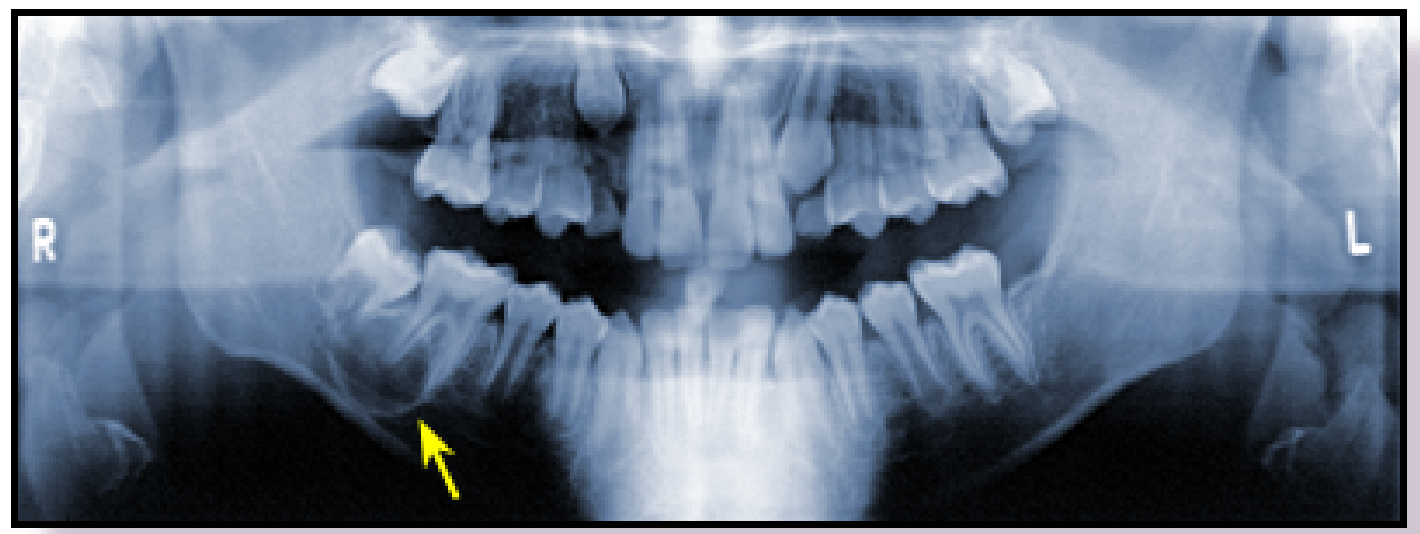

\begin{abstract}
Odontogenic keratocyst (OKC) is a cyst of tooth origin with an aggressive clinical behavior including a high recurrence rate. OKC demographics in the northwestern United States are presented and compared to those reported elsewhere. A total of 430 cases were obtained from 393 patients of the northwest region over a period of 15 years. Data evaluated included: site, gender, age, race, and association with bifid-rib basal cell nevus syndrome (Gorlin syndrome). Site distribution of the northwest group was similar to that of international groups. For the northwest group, the most common lesion location was the body of the mandible. Gender distribution in the northwest group appeared similar to other reports made in Denmark, England, Japan, and other regions in the United States. However, when gender distribution was compared by decade of life, the northwest group had the largest cluster of males in the fourth decade and of females in the second decade. The greatest frequency in both genders occurred in the third decade. There were 18 of $258(6.9 \%)$ male patients with OKC under age 10 in the northwest group and nearly $80 \%$ of the patients were Caucasian. The race factor is rarely described in other reports. Gorlin's syndrome was present in $5 \%$ of the patients, with a higher distribution in the first and second decades. In conclusion, this is the first report of OKC cases from the Pacific Northwest region of the United States of America.

Keywords: Odontogenic keratocyst, OKC, northwestern USA, comparison, demographics, Gorlin syndrome
\end{abstract}




\section{Introduction}

The odontogenic keratocyst (OKC) was first described in $1876^{1}$ and named by Phillipsen in $1956 .^{2}$ It is one of the most aggressive odontogenic cysts of the oral cavity. OKC is known for its rapid growth ${ }^{3-5}$ and its tendency to invade the adjacent tissues including bone..$^{1,5-7}$ It has a high recurrence rate $^{5,8,9}$ and is associated with the basal cell nevus syndrome. ${ }^{10,11}$ Harring et al. best characterized this cyst by stating that "After thirty years of study, questions related to the histogenesis, pathogenesis, histology, high recurrence rate, and neoplastic potential of the OKC are still being debated."12

Odontogenic keratocysts are generally thought to be derived from either the epithelial remnants of the tooth germ, or the basal cell layer of the surface epithelium. ${ }^{13-21}$ The majority of patients are in the age ranges of $20-29$ and $40-59,,^{22}$ but cases ranging from 5 to 80 years have been reported. ${ }^{12,23}$ In one study the average age of males was 9.7 years older than that of females. ${ }^{12}$ The distribution between sexes varies from equality to a male to female ratio of 1.6:1, except in children. ${ }^{12,24-26}$ Odontogenic keratocysts may occur in any part of the upper and lower jaw with the majority occurring in the mandible, most commonly in the angle of the mandible and ramus. . $^{12,22,25,27,28}$

Radiographically, odontogenic keratocyst present predominently as a unilocular radiolucency with well-developed sclerotic borders (Figure 1A).

\section{Radiographic Presentation of the Odontogenic Keratocyst}

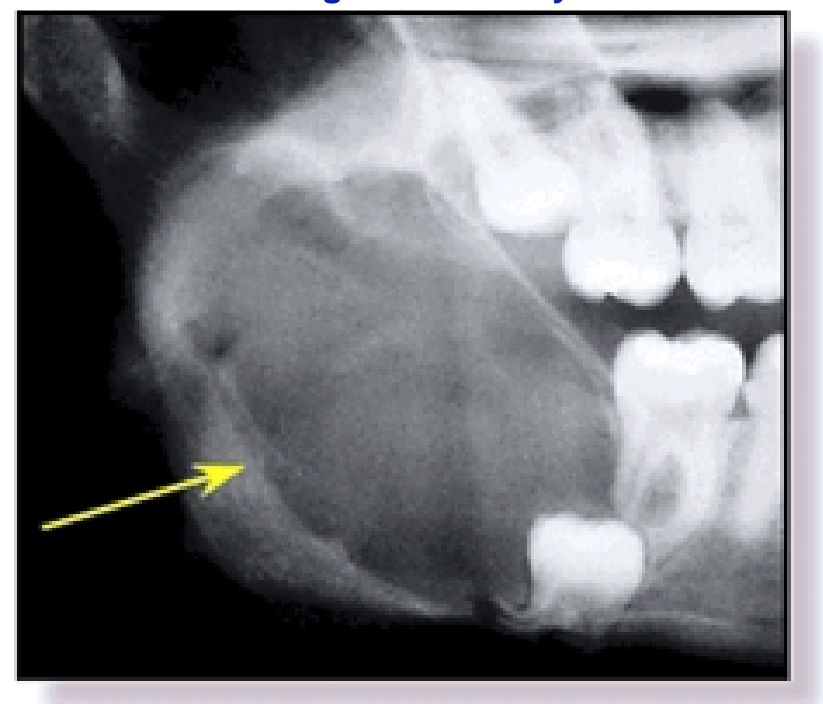

Fig. 1A - Large OKC involving an impacted third molar tooth, unilacular with scalloped borders, representing the typical radiographic appearance of OKC.
They may also present as a multilocular radiolucency with a ratio of unilocular to multilocular varying from $3: 112$ to $1: 1.3 .^{24}$ Perhaps the multilocular appearance described in the latter was more of a unilocular with scalloped borders lacking true compartment formation (Figure 1B). ${ }^{24}$

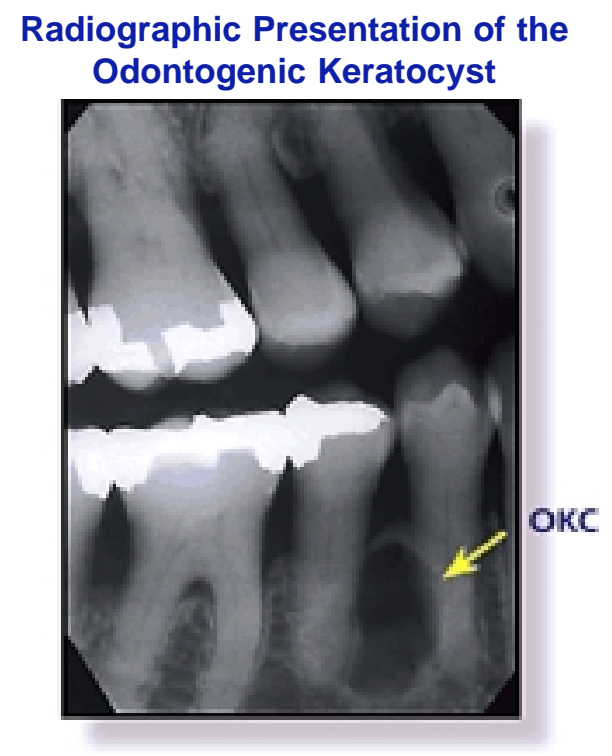

Odontogenic keratocysts of the maxilla are smaller in size compared to the mandible. When they are large, they tend to expand bone. No difference in site distribution was seen between unilocular and multilocular cysts. ${ }^{12}$ These lesions can also present as a small and oval radiolucency between teeth simulating a lateral periodontal cyst (Figure 1A). They can also appear as a radiolucency simulating a residual apical periodontal cyst (Figure 1C).

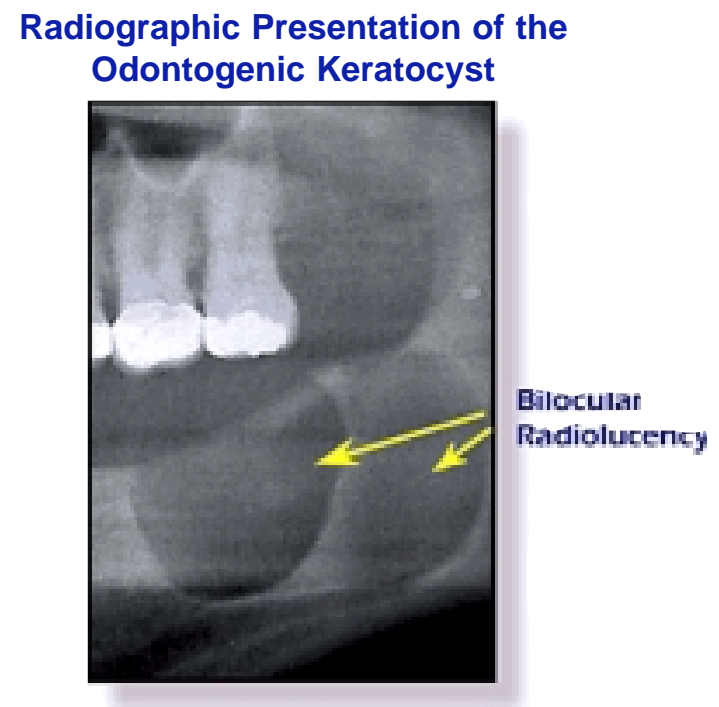

Fig. 1C - Large and well-demarcated bilocular radiolucency with cloudy appearance in the posterior mandible in an area of extracted teeth. The cloudy appearance is believed to be due to the presence of keratin. 
Multiple keratocysts (Figures 1D \& 1E) are frequently associated with the bifid-rib basal cell nevus syndrome (Gorlin syndrome). ${ }^{25}$ Unilocular radiolucency with sclertotic border is also know to be associated with Gorlin syndrome (Figure 1E). For purposes of this paper, the bifid-rib basal cell nevus syndrome will be referred to as the Gorlin syndrome. Some authors suggest that as many as half of odontogenic keratocysts are related to the Gorlin syndrome. ${ }^{29}$ These lesions grow to sizes larger than any other odontogenic cyst. They more often penetrate the bone rather than expand it and grow in an anterior to posterior direction..$^{30}$ Despite this aggressive growth, they often remain asymptomatic. ${ }^{31}$

\section{Radiographic Presentation of the Odontogenic Keratocyst}

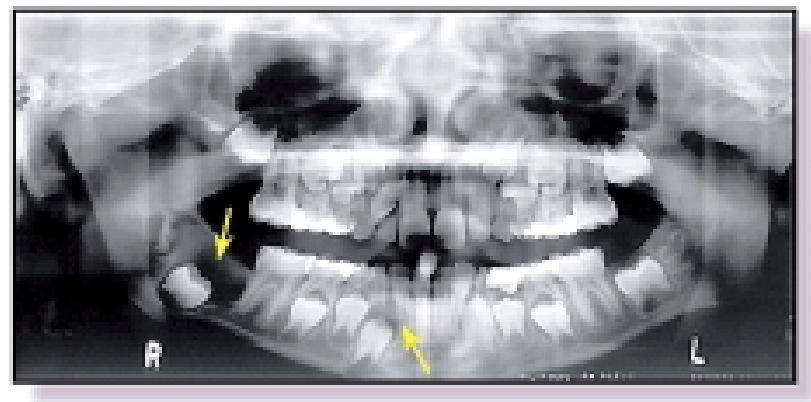

Fig. 1C - Multiple radiolucencies involving the left posterior mandible and left mandibular canine. This is associated with a known Gorlin syndrome patient.

\section{Radiographic Presentation of the Odontogenic Keratocyst}

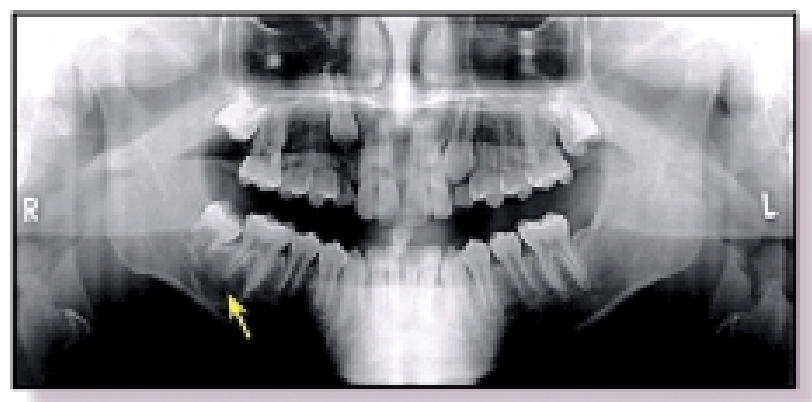

Fig. 1C - Multiple corticated radiolucencies in the corticated unilocular radiolucency in the left posterior mandible with typical anterior to posterior direction of growth in an area of extracted teeth.

Odontogenic keratocysts are significant clinical entities due to their tendency for recurrence and aggressive behavior. These cysts are known to have a high recurrence rate ranging between 13 to $60 \%$. 5,6 Complete surgical removal is the treatment of choice. An excellent reference for various modalities is by Voorsmit and Stoelinga where multiple surgical approaches with and without the use of Carnoy's fixative solution is recommended. In brief, this study shows that Carnoy's solution is effective in reducing recurrence rate when patients were followed for two years. ${ }^{32}$ Other investigators advocate marsupialization and occasionally resection for the more aggressive cysts that tend to perforate buccal and lingual bone. ${ }^{33}$ Resection is a rare modality of treatment. Conservative surgical removal and long-term follow-up is the treatment of choice by most clinicians.

Seeking to expand the present knowledge of this disease, 430 cases of OKC from 393 patients were examined in a group representative of the Pacific Northwestern population of the United States. This report discusses the demographic findings including age, gender, race, site of lesion, and association with the Gorlin syndrome. The report compares the Northwest data to that of the previous reports describing cohorts in the United States and worldwide. 
Four hundred and thirty cases from 393 patients were collected from the records of the Oral Pathology Biopsy service in the Department of Oral \& Maxillofacial Surgery at the School of Dentistry, University of Washington in Seattle. These cases represented $1 \%$ of all oral biopsies $(40,568)$ performed over 15 years. The patient records were reviewed for demographics and compared to demographics of published reports from the literature. Table 1 describes cohorts of OKC patients from the United States excluding the Northwest to cohorts elsewhere in other parts of the world. The Northwest group of cases are referred to as Northwest (NW), since the patient pool is derived from the states of Washington, Idaho, Montana, and Utah. However, the majority of these cases (over 95\%) are from the state of Washington. All cases were reviewed histologically by one examiner. Those that did not fit the characteristic histological criteria as described widely in the literature as having uniform thickness, corrugated and keratinized lining epithelium, and a palisaded basal cell layer were eliminated from the study. This report will bring forward data on the demographics of odontogenic keratocyst in the northwest (which has not previously been published) and compares it to data from other regions of the USA and other countries.

\section{Results}

Age: The age range was 7-93 years. Examined by decade of age, 23 of these cases were in the first decade. Eight of these were from a single family of three brothers of Asian origin. Decades two and four had similar numbers of cases and the most cases. Decades three, five, six, and seven were closely distributed with moderate incidence. The numbers tapered from decade 8 and older (Figure 2).
Figure 2.

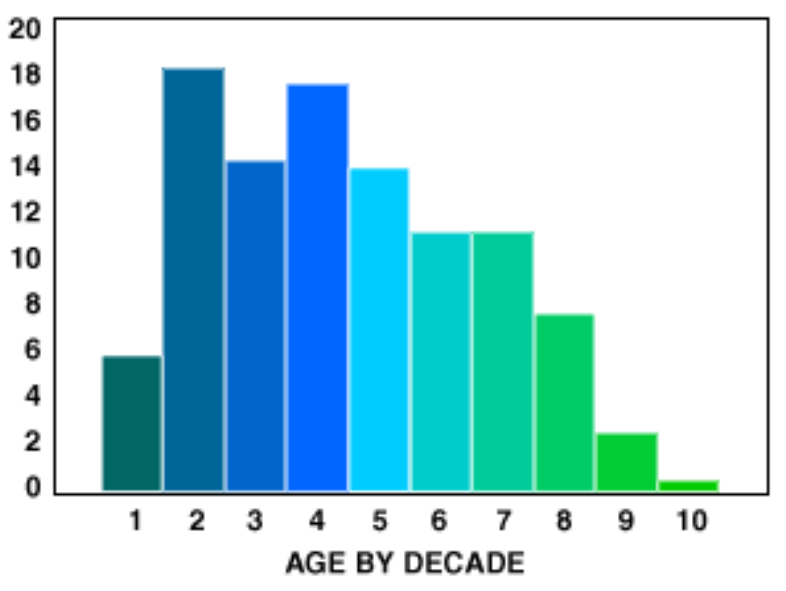

Gender: When examining the gender of patients, data were also segmented by decade (Figure 3). In the NW population there was a slightly higher percentage of males in all decades except for the second, in which there was almost equal representation. A predominance of females was seen in the ninth and tenth decades. The NW population was the second study group reporting patients in the tenth decade (Table I).

Figure 3.

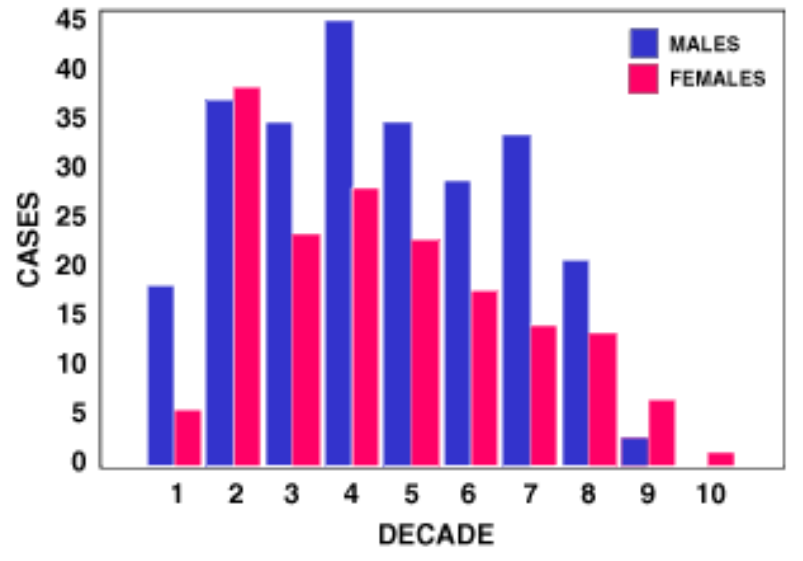


Table 1. Age Range Distribution of Comparative Studies of Keratocysts

\begin{tabular}{|c|c|c|c|c|c|c|c|c|c|c|c|c|c|}
\hline \multirow[b]{2}{*}{ Year } & \multirow[b]{2}{*}{ Author } & \multirow[b]{2}{*}{ Country } & \multirow{2}{*}{$\begin{array}{c}\# \\
\text { Cysts }\end{array}$} & \multicolumn{10}{|c|}{ Decade } \\
\hline & & & & 1 & 2 & 3 & 4 & 5 & 6 & 7 & 8 & 9 & 10 \\
\hline 1963 & Pindborg & Denmark & 30 & \multicolumn{10}{|c|}{ Range $15-75$} \\
\hline 1977 & Brannon & USA-C & 312 & 2 & 52 & 54 & 44 & 38 & 37 & 27 & 10 & 2 & 1 \\
\hline 1985 & Zachariades & Greece & 16 & & 1 & 2 & 2 & 4 & 3 & 3 & 1 & & \\
\hline 1986 & Chen & Taiwan & 16 & & 1 & 5 & 9 & 1 & & & & & \\
\hline 1987 & Woolgar & England & 228 & 2 & 35 & 43 & 38 & 21 & 28 & 28 & 20 & & \\
\hline 1987 & Woolgar & England & 432 & 6 & 86 & 82 & 73 & 41 & 51 & 50 & 28 & 5 & \\
\hline 1987 & Patridge & England & 60 & & 10 & 20 & 7 & 6 & 10 & 14 & & 2 & \\
\hline 1988 & Haring & UAS-C & 60 & 2 & 7 & 18 & 6 & 6 & 7 & 12 & 2 & & \\
\hline 1988 & Kondell & Sweden & 29 & & 1 & 6 & 8 & 2 & 8 & 2 & 2 & & \\
\hline 1990 & Kakarantza & Greece & 87 & & 12 & 7 & 10 & 15 & 20 & 7 & 8 & & \\
\hline 1992 & Crowley & USA-E & 449 & \multicolumn{10}{|c|}{ Mean age 37.5} \\
\hline 1995 & Anad & USA-SE & $50 p$ & \multicolumn{10}{|c|}{ Range 8-85 } \\
\hline 1995 & Nakamura & Japan & 95 & 1 & 25 & 21 & 18 & 18 & 4 & 2 & 5 & 1 & \\
\hline 1996 & $\begin{array}{l}\text { Valiente- } \\
\text { Riveria }\end{array}$ & USA-NW & 430 & 23 & 73 & 57 & 71 & 56 & 45 & 45 & 31 & 9 & 1 \\
\hline 1991 & Brondum & Denmark & $44 p$ & 1 & 5 & 8 & 4 & 10 & 7 & 3 & 5 & 1 & \\
\hline 1996 & El-Hajj & Sweden & 62 & & 9 & 15 & 4 & 9 & 5 & 10 & 4 & & \\
\hline
\end{tabular}

Lesion Site: When examining the site of lesions by major geographic areas in the northwest with other geographic locations examined in this report, the mandible was affected in over $57 \%$ of all individual reports. Although the data is not shown in Figure 4, there was an average of $74 \%$

Figure 4.

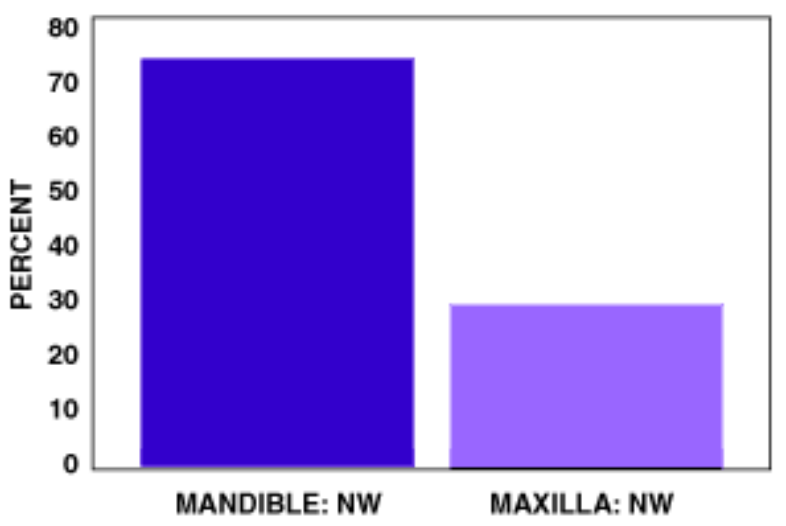

of all reported cases affecting the mandible. The NW data was further subdivided into areas within the jaws, i.e., anterior and posterior of both jaws. The data clearly showed a greater incidence in the body of the mandible with the posterior maxilla being second (Figure 5).

Figure 5.

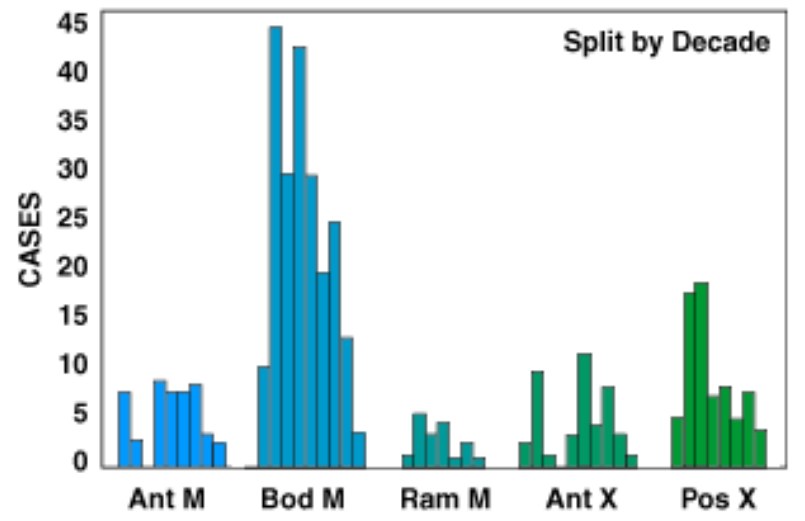




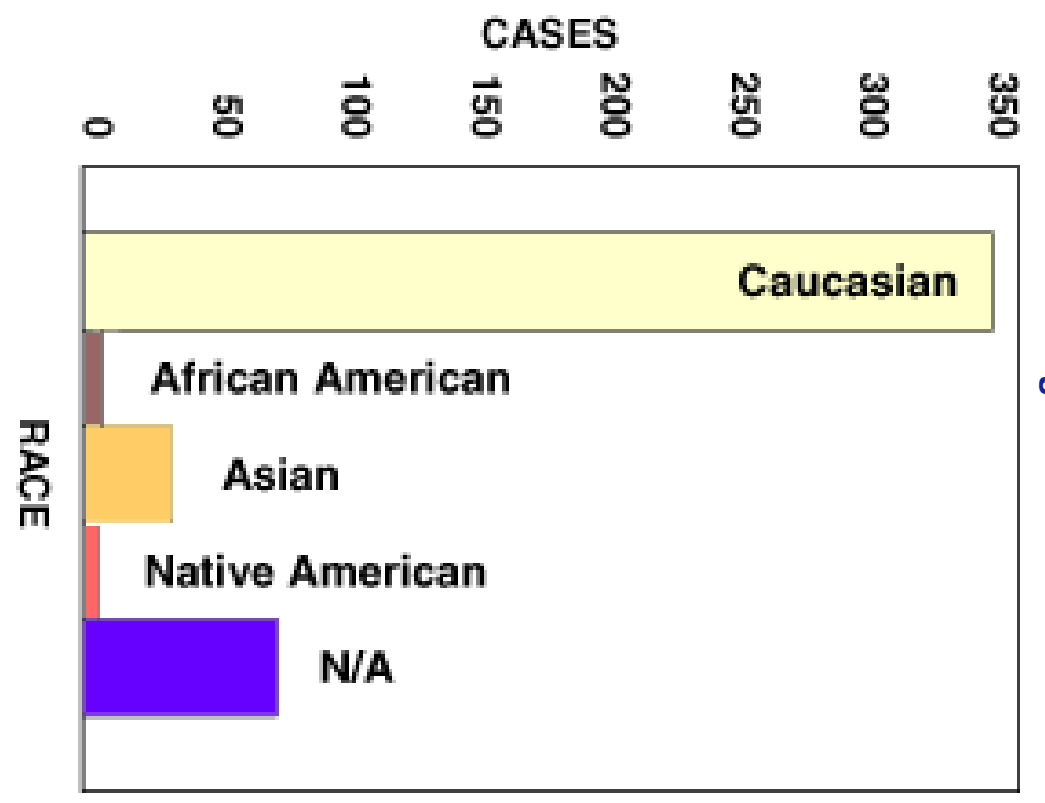

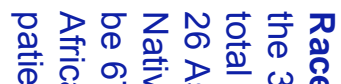
焉

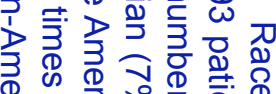

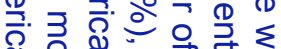

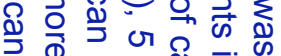
की

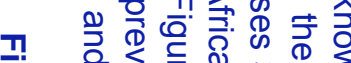

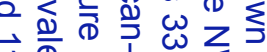
蛋

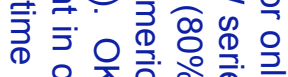
उ

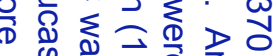
实 虫

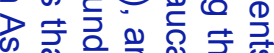

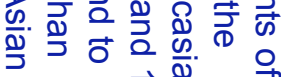

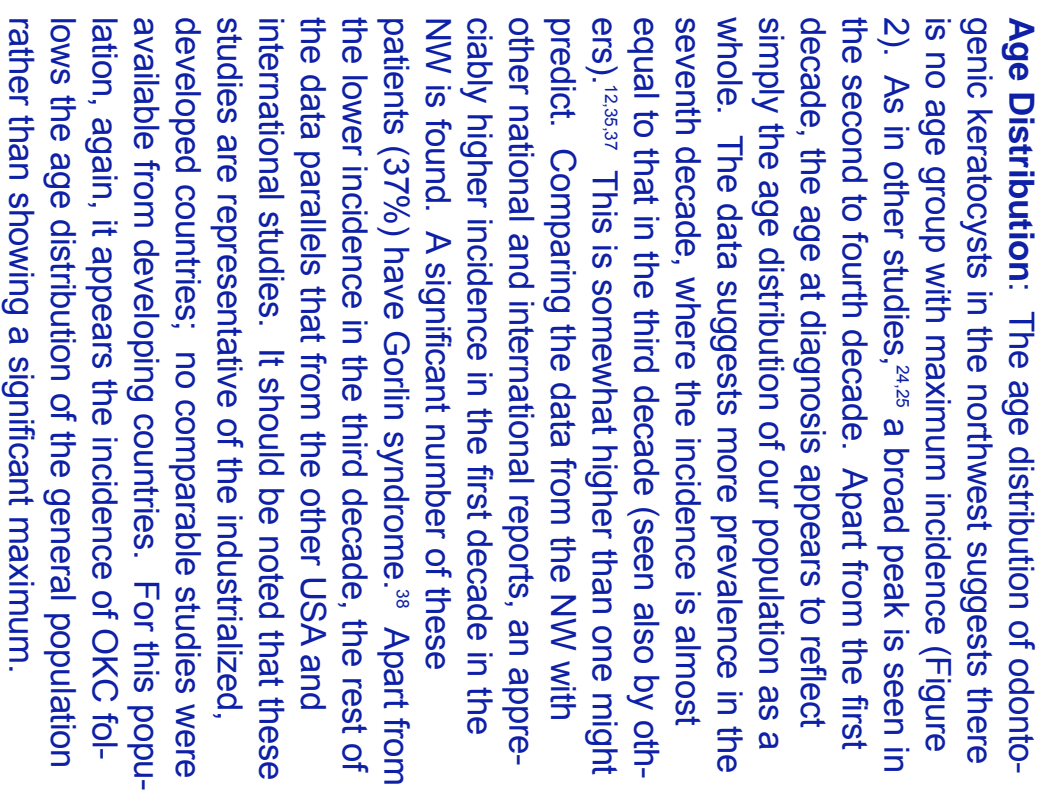

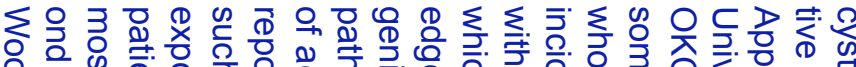

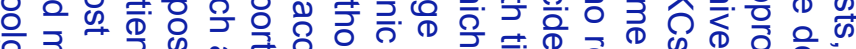

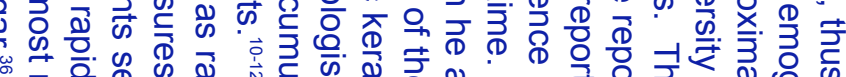

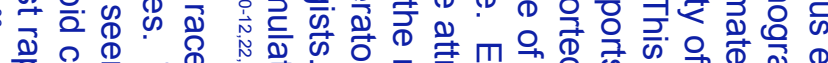

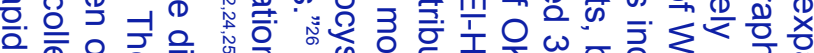

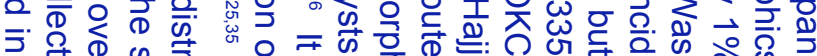

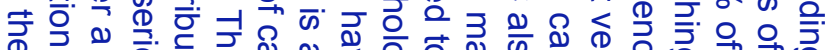
(1)

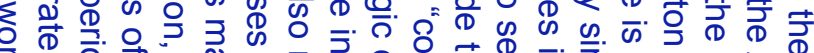

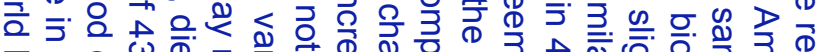

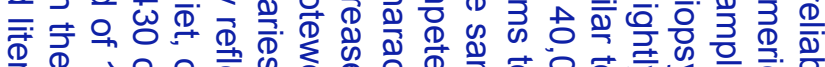
心 क

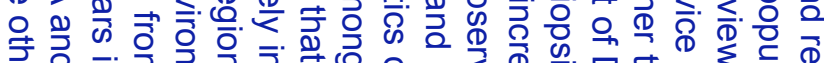

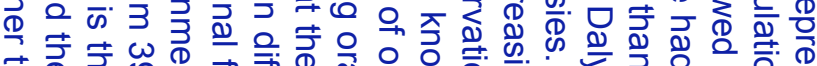

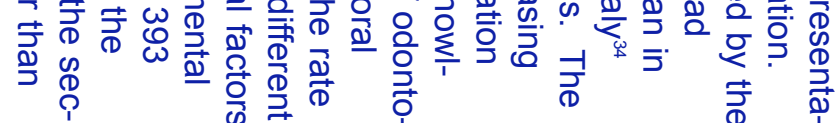


Gender Distribution: The cases of the NW group segmented by decade were further divided by gender. In virtually all decades, except the ninth and tenth, there is a preponderance of males over females in the incidence of odontogenic keratocysts (Figure 4). Only in the upper two decades is there a preponderance of females which may reflect the fact that more females than males survive to this age. Considering the gender without the decade factor, the male to female ratio was 3:2. Comparing this data against the national ${ }^{11,12,23,29}$ and other international $\left.\right|^{9,36,37,40,43}$ reports, the overall gender distribution is virtually identical. Examining the gender distribution as a function of age group, there are marked differences at both ends of the age range (Figure 3). In the first decade, the distribution in the NW is more than 2:1 towards the male. In other published reports the number of cases that included both gender and decade data are not sufficient for statistical evaluation. In the third through the eighth decades, the NW figures show a male preponderance until the ninth decade when longevity finally outweighs susceptibility.

Lesion Site: Odontogenic keratocysts have a tendency to occur in any part of the mandible and maxilla, but the majority, almost $70 \%$, arise in the body of the mandible. ${ }^{12,22,24,25}$ This is an area common to many benign but aggressive odontogenic tumors such as ameloblastoma. This is also a common location for dentigerous cysts and other odontogenic cysts. The NW data is compatible with that of the literature in that the majority of cases occurred in the body of the mandible (Figure 5).

Race Distribution: Unfortunately, a full comparison cannot be made since the only other studies reporting a racial distribution are those of Rachanis, et al. (49 cases), Crowley (449 cases), and Brannon (283 patients). ${ }^{44,11,10}$ The distribution from these studies is shown in Table 2.
Table 2. Odontogenic Keratocysts by Race Distribution

\begin{tabular}{|c|c|c|}
\hline Study & Caucasian & $\begin{array}{c}\text { African } \\
\text { American }\end{array}$ \\
\hline Rachanis & 43 cases & 6 cases \\
\hline Crowley & 309 cases & 54 cases \\
\hline Brannon & 255 cases & 6 cases \\
\hline
\end{tabular}

The NW data (Figure 6) was more consistent with that of the Brannon study which represented the central USA. The Crowley study represented the Mississippi area with a higher African American population compared to the NW and central United States. The Rachanis study ${ }^{44}$ showed that a wide difference in distribution was reported when compared to the USA data and a closer ratio between white and black populations in Africa when compared to the USA. This is interpreted to be due to the larger black population.

It is clear, however, that OKC is a disease predominantly of Caucasian populations and, if one may judge from the limited evidence provided by comparing the number of cases in the different reports, a disease chiefly of Northern Europeans; a group which is heavily represented in the NW.

OKC in Children and Gorlin Syndrome: Gorlin syndrome has been studied as an autosomal dominant disorder arising from defects on chromosome 9q23.1-q31. ${ }^{41}$ This syndrome is often identified in juvenile kindred. ${ }^{42}$ Some authors suggest that about half of OKC cases are associated with this syndrome. ${ }^{10}$ When so associated, the cysts are usually multiple and the patient is younger. ${ }^{30}$ 


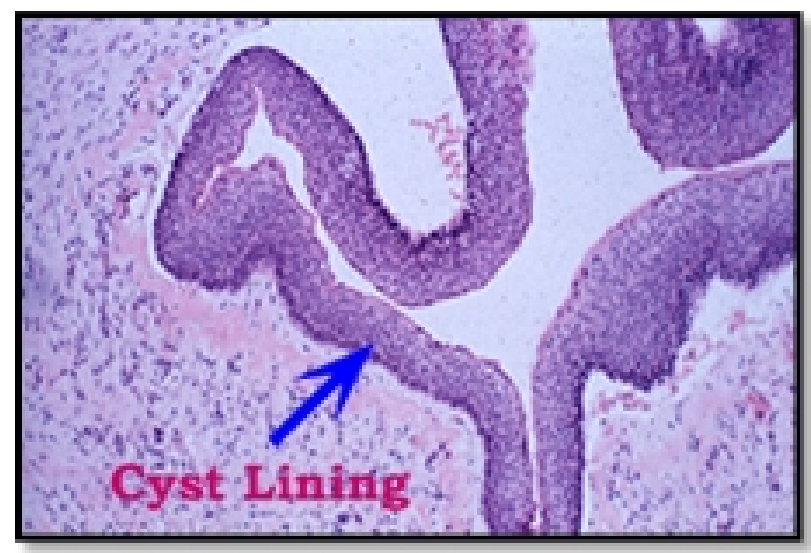

This $H \&$ E stained histologic slide illustrates the low power of a typical OKC made up of thin and uniform keratinized stratified squamous epithelium artifactually separated from the underlying connective tissue wall (magnification X200)

Woolgar describing a population in England found that of 682 OKCs reported, ${ }^{36} 164$ were from 60 patients with Gorlin syndrome. Of 87 cases from Athens, 7 (8.8\%) were associated with Gorlin syndrome..$^{35}$ All cases associated with Gorlin syndrome had parakeratinized epithelial lining as reported by others.3,10,39 In a third study of 60 patients, 9 were age 20 or younger. This case showed a 6:1 male to female preponderance in the age range 11 to 20 years. ${ }^{12}$ Finally, in another series of 57 OKC where age ranged from 11 to 78 years, 9 of 57 subjects were under 20 years of age. ${ }^{26}$ A 14-year old boy with Gorlin syndrome had an OKC of the mandible that showed epithelial atypia. ${ }^{10}$ In the northwest group, the largest number of Gorlin syndrome patients was in the first decade, three of which were brothers. On the other hand, some suggest that odontogenic keratocysts are found only in patients with permanent teeth or those who are edentulous.15 However, there is at least one report of OKC in a 5 year-old.12 Clearly, there is much to learn about the origin of this cyst and its association with Gorlin syndrome. However, the NW data as well as others show a higher incidence of Gorlin syndrome with younger patients especially under 10 years of age. This is shown in Figure 1D and Figure $1 \mathrm{E}$ which are panoramic radiographs of two siblings. It seems appropriate that OKC of patients under 20 years of age should be followed by genetic counseling and medical examination.

Due to the lack of information on treatment, recurrence, and follow-up data, this study did not address the recurrence rate in the Northwest population.

\section{Conclusion}

This is the first report of OKC cases from the Pacific Northwestern region of the United States of America. 


\section{References}

1. Voorsmit RACA. The incredible keratocyst. M.D. Dissertation, The Catholic University of Nijmegen, the Netherlands, 1984.

2. Philipsen HP. Om keratocyster (kolesteatom) I kaekberne. Tandlaegegebladet 1956;60: 963-81.

3. Broume RM. The odontogenic keratocyst - histological features and their correlation with clinical behavior. Br Dent J 1971;131: 249-59.

4. Sharffetter K, Balz-Herrmann C, Lagrange W, Koberg W, Mittermayer C. Proliferation kinetics - study of the growth of keratocysts. J Cranio-Max-Fac Surg 1989;17: 226-33.

5. Stoelinga PJW, Bronkhorst FB. The incidence, multiple presentation and recurrence of aggressive cysts of the jaws. J Cranio-Max-Fac Surg 1988;16: 184-95.

6. Browne RM. The odontogenic keratocyst - clinical aspects. Br Dent J 1970;128: 225-31.

7. Lund VJ. Odontogenic keratocyst of the maxilla: a case report. Br J Oral Maxillofac Surg 1985;23: 210-15.

8. Forssell K, Forssell H, Kahnberg KE. Recurrence of keratocysts. A long-term follow-up study. Int J Oral Maxillofac Surg 1988;17: 25-8.

9. Pindborg JJ, Hansen J. Studies on odontogenic cyst epithelium. II. Clinical and roentgenologic aspects of odontogenic keratocysts. Acta Pathol Microbiol Scand 1963;58: 283-94.

10. Brannon RB. The odontogenic keratocyst. A clinicopathologic study of 312 cases. Part II. Histologic features. Oral Surgery 1977;43: 233-55.

11. Crowley TE, Kaugars GE, Gunsolley JC. Odontogenic keratocysts: a clinical and histologic comparison of the parakeratin and orthokeratin variants. J Oral Maxillofac Surg 1992;50: 22-6.

12. Haring JI, Van Dis ML. Odontogenic keratocysts; a clinical, radiographic and histopathologic study. Oral Surg Oral Med Oral Pathol 1988;66: 145-53.

13. Hjorting-Hansen E, Andreasen JO, Robinson LH. A study of odontogenic cysts with special reference to location of keratocysts. Br J Oral Surg 1969;7: 15-23.

14. Rud J, Pindborg JJ. Odontogenic keratocysts: a follow-up study of 21 cases. J Oral Surg 1969;27: 323-30.

15. Panders AK, Hadders HN. Solitary keratocysts of the jaws. J Oral Surg 1969;27: 931-38.

16. Lucas RB. Pathology of Tumors of the Oral Tissues, 3rd ed. Edinburgh, Churchill Livingstone, 1976, p 358.

17. Sher MB, Stoopack JC. Odontogenic keratocyst. Report of a case. Oral Surg 1974;37: 518-25.

18. Robinson HBG. Primordial cyst versus keratocyst. Oral Surg 975;40: 362-66.

19. Altini M, Cohen M. The folicular primordial cyst-odontogenic keratocyst. Int J Oral Surg 1982;2: 175-82.

20. Main DMG. Epithelial jaw cysts: a clinicopathological reappraisal. Br J Oral Surg 1970;8: 114-19.

21. Wright JM. The odontogenic keratocyst: orthokeratinized variant. Oral Surg 1981;51: 609-18.

22. Brondum N, Jensen VJ. Recurrence of keratocysts and decompression treatment. A long-term follow-up of forty-four cases. Oral Surg Oral Med Oral Pathol 1991;72: 265-69.

23. Anand VK, Arrowood JP Jr and Krolls. Odontogenic keratocyst: a study of 50 patients. Laryngoscope 1995;105: 14-6.

24. Chen $\mathrm{C}-\mathrm{H}$, Lin C-C. Clinical and histopathological study of the odontogenic keratocyst - a follow-up study of 16 cases. Kaohsiung J Med Sci 1986;2: 601-07.

25. Woolgar JA, Rippin JW, Browne RM. A comparative study of the clinical and histological features of recurrent and non-recurrent odontogenic keratocysts. J Oral Pathol 1987;16: 124-28.

26. El-Hajj G, Anneroth G. Odontogenic keratocysts - a retrospective clinical and histological study. Int J Oral Maxillofac Surg 1996;25: 124-29.

27. Vedtofte P, Praetorious F. Recurrence of the odontogenic keratocyst in relation to clinical and histological features. Int J Oral Surg 1979;8: 412-20.

28. Forssell K. The primordial cyst: a clinical and radiographic study (Thesis). Proc Finn Dent Soc 1980;76: 129-74.

29. Brannon RB. The odontogenic keratocyst. A clinicopathological study of 312 cases. Part I. Clinical features. Oral Surg 1976;42: 54-71.

30. Zachariades N, Papanicolaou S, Triantafyllou D. Odontogenic keratocysts: Review of the literature and report of sixteen cases. J Oral Maxillofac Surg 1985;43: 177-182.

31. Keith DA. Macroscopic satellite cyst formation in the odontogenic keratocyst. Report of two cases. Oral Surg 1973;35: 21-7.

32. Voorsmit RACA, Stoelinga PJW, van Haelst UJGM. The management of keratocysts. J Maxillofac Surg 1981;9: 228-236. 
33. Irvine GH, Bowerman JE. Mandibular keratocyst: Surgical management. Br J Oral Maxillofac Surg 1985;23: 203-209.

34. Daley TD, Wysocki GP, Pringle GA. Relative incidence of odontogenic tumors and oral and jaw cysts in a Canadian population. Oral Surg Oral Med Oral Pathol 1994;77: 276-280.

35. Kakarantza-Angelopoulou E, Nicolatou O. Odontogenic keratocysts: clinicopathologic study of 87 cases. J. Oral Maxillofac Surg 1990;48: 593-99.

36. Woolgar JA, Rippin JW, Browne RM. The odontogenic keratocyst and its occurrence in the nevoid basal cell carcinoma syndrome. Oral Surg Oral Med Oral Pathol 1987;64: 727-30.

37. Partridge M, Towers JF. The primordial cyst (odontogenic keratocyst): its tumour-like characteristics and behaviour. Br J Oral Maxillofac Surg 1987;25: 271-79.

38. Gorlin RJ. Nevoid basal-cell carcinoma syndrome. Medicine 1987;66: 98-113.

39. Browne RM. The odontogenic keratocyst, histological features and their correlation with clinical behaviour. Br Dent J 1971;131: 249-59.

40. Woolgar JA, Rippin JW, Browne RM. A comparative histological study of odontogenic keratocysts in basal cell nevus syndrome and control patients. J Oral Pathol 1987;16: 75-80.

41. Fardon PA, Norris D.J, Hardy C. et al. Analysis of 133 meioses places the genes for nevoid basal cell carcinoma (Gorlin) syndrome and Fanconi anemia group $\mathrm{C}$ in a 2.6-cM interval and contributes to the fine map of 9q22.3, Genomics. 1994;23: 486-489.

42. Gailani MR, Bale SJ, Leffell DJ. et al. Developmental defects in Gorlin syndrome related to a putative tumor suppressor gene on chromosome 9. Cell 1992;69: 111-117.

43. Nakamura T, Ihisda J, Nakano Y, Ishii T. et al. A study of cysts in the oral region. Cysts of the jaw. J Nihon Univ Sch Dent 1995;37: 33-40.

44. Ranchis CC, Shear, M. Age-Standarized incidence rates of primordial cyst (keratocyst) on the Witwatersrand, Community Dent. Oral Epidemiol. 1978;6: 296-299.

\section{About the Authors}

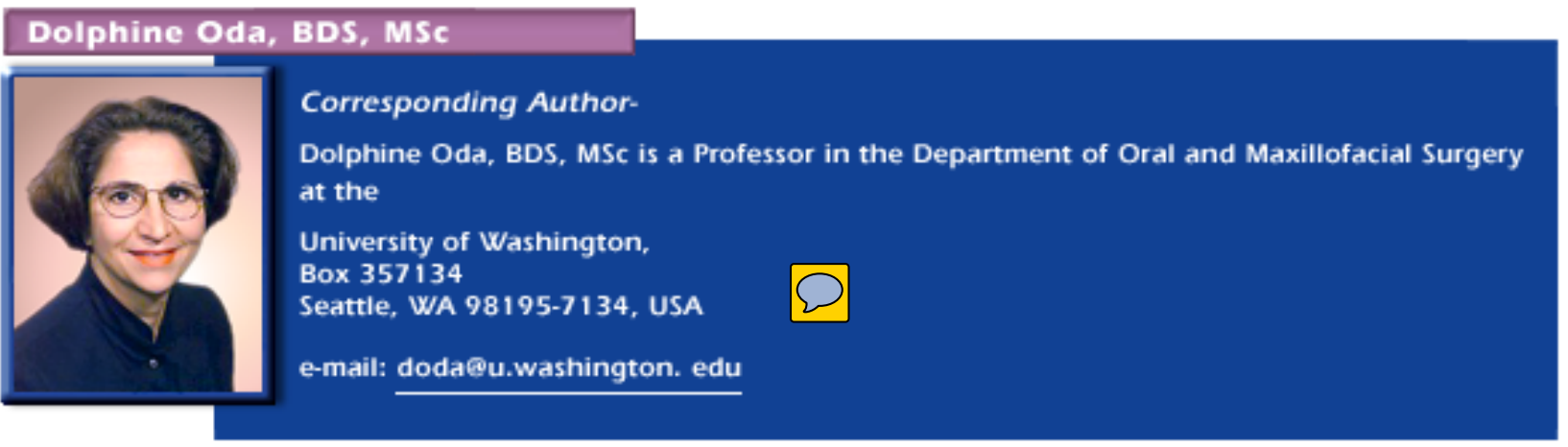

\section{Co-Authors}

\begin{tabular}{|l|l|}
\hline $\begin{array}{l}\text { Valiente Rivera, DDS } \\
\text { Ph.D Candidate }\end{array}$ & $\begin{array}{l}\text { N. Ghanee, DDS, MSD } \\
\text { Oral Pathologist } \\
\text { Department of Oral Biology } \\
\text { School of Dentistry } \\
\text { University of Washington }\end{array}$ \\
\hline $\begin{array}{l}\text { E.A., Kenny, MA } \\
\text { Professor Emeritus } \\
\text { Department of Laboratory Medicine } \\
\text { School of Medicine } \\
\text { University of Washington }\end{array}$ & $\begin{array}{l}\text { K.H., Dawson, BDS } \\
\text { Assistant Professor } \\
\text { Department of Oral and Maxillofacial Surgery } \\
\text { School of Dentistry } \\
\text { University of Washington }\end{array}$ \\
\hline
\end{tabular}

